\title{
Neighbor Loaves program aims to maintain regional grain value chains and feed the community
}

\author{
Amy Halloran* \\ Troy, New York
}
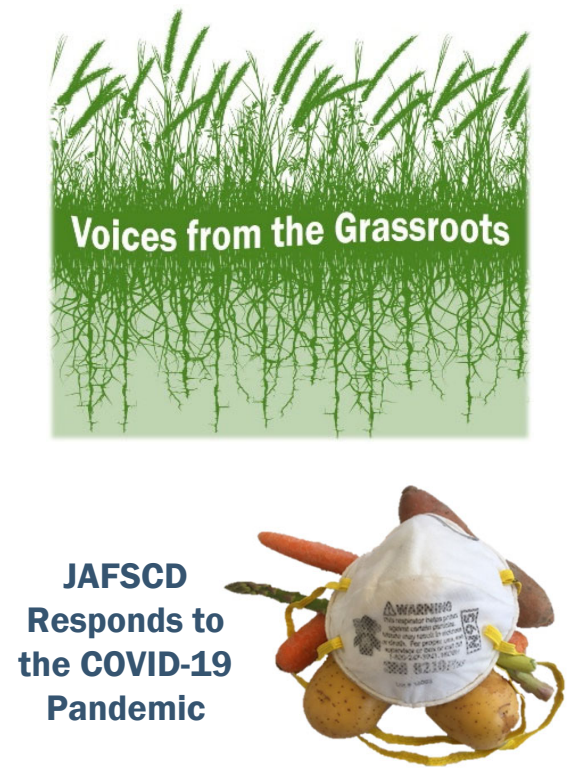

Submitted April 24, 2020 / Published online May 8, 2020

Citation: Halloran, A. (2020). Neighbor Loaves program aims to maintain regional grain value chains and feed the community. Journal of Agriculture, Food Systems, and Community Development, 9(3), 41-44. https://doi.org/10.5304/jafscd.2020.093.031

Copyright $(2020$ by the Author. Published by the Lyson Center for Civic Agriculture and Food Systems. Open access under CC-BY license.

$\mathrm{I}_{\mathrm{t}}^{\mathrm{n}}$ $\mathrm{n}$ the surreality of March 2020, as states closed the doors on business, my colleague Alyssa Hartman had a great idea. Watching businesses struggle, she wondered what she could do as a non-essential worker to help farmers and bakers. We set up a time to chat.

Alyssa is executive director of the Artisan Grain Collaborative (AGC), a group of individuals and organizations working to strengthen and promote the diversity of grains on the landscape in the Upper Midwaest. She and I brainstorm on the phone a lot, thinking about actions to help create awareness of grains and rebuild regional grain networks. But when we spoke_-as the pandemic be-

* Amy Halloran wrote The New Bread Basket, a record of and template for the revival of regional grain production. Her activism for specialty grains and for changing emergency feeding programs shares a common thread: of restoring human values to the work of farming and the acts of feeding ourselves and each other. Amy can be contacted at 221 Tenth Street, Troy, NY 12180 USA, or halloran15@gmail.com. gan to change everyday life-I didn't need to think hard about strategy. I just listened and said YES.

She described a plan to ask consumers to purchase loaves of bread that bakers would make for food pantries. These particular loaves would be made from regional flour, and customers would pay full price for them, which would help bakeries meet expenses. I loved the idea immediately.

"None of us wants to emerge after six months and have everything gone," she told me. These Neighbor Loaves would help businesses survive during the shutdown, giving bakeries work to keep paying rents and payroll, and assuring mills and farms that their goods had somewhere to go. Plus, it would address bread shortages for emergency feeding programs. Alyssa and another AGC member, Brianna Fiene of University of WisconsinMadison's Center for Integrated Agricultural Systems, worked out the nuts and bolts of the system, made graphics and Google Forms to help onboard participants, and made this thing happen in Madi- 
son, Minneapolis, Chicago, and Bloomington, Indiana-for a start.

Here's how it works: Community members are invited to purchase Neighbor Loaves that they want to donate rather than eat, through participating bakeries' online stores. Bakers craft these loaves with at least $50 \%$ local flour, and the bread is distributed to area food pantries and community feeding organizations. Nearly 5,000 loaves have been purchased in the Upper Midwest since the program launched on March 28, 2020. Loaf "matching" is happening, too: local businesses have offered to purchase a certain number of loaves equal to the number ordered by community members to help keep bakeries baking and families eating. The effort has been picked up elsewhere, as well, connecting regional grain economies to people who need food in the Northeast, Pacific Northwest, and Mid-Atlantic regions. Alyssa has even gotten a note asking for support launching the program in New Zealand.

Neighbor Loaves strengthens local and regional food systems by connecting communities of farmers, millers, bakers, and eaters. As empty grocery store shelves during the COVID-19 pandemic have evidenced, resilient regional staple crop value chains mean community food security.

One of my favorite bakeries, Hewn Bread in Evanston, Illinois, has made more than 1,500 Neighbor Loaves for the nearby Hillside Food Pantry. Customers had been asking what they could do to help, and now they've got a system to support the bakery in a practical way, while also helping the growing numbers of food-insecure people in their neighborhood. In the first 20 minutes the Neighbor Loaves program appeared on Hewn's website, people bought 40 loaves. Now, many weeks into the project, people are still buying more than their own bread. Feeding others has become a part of the bread-shopping habit.

"We can't help in the way we usually help each other," one customer remarked. "Our routes of helping are broken."

The program is really firming up the footing for some farms and mills that are facing uncertainty this spring. Meadowlark Organics in Ridgeway, Wisconsin, is one of the farms whose flour is going into Neighbor Loaves at Hewn, ORIGIN
Breads, and Madison Sourdough. Having the Neighbor Loaves platform in place adds a muchneeded sense of security as the farm plants spring crops.

That sense of security is shared in the project.

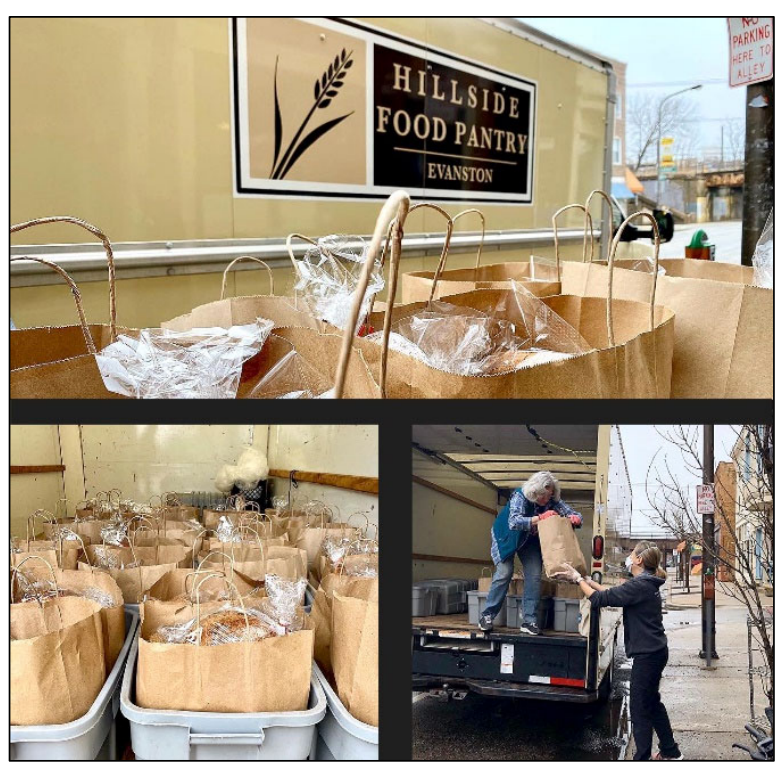

Hewn Bread hands off a 300-loaf batch of Neighbor Loaves baked with grain from Janie's Mill to Hillside Food Pantry, which serves residents in Hewn's hometown of Evanston, Illinois.

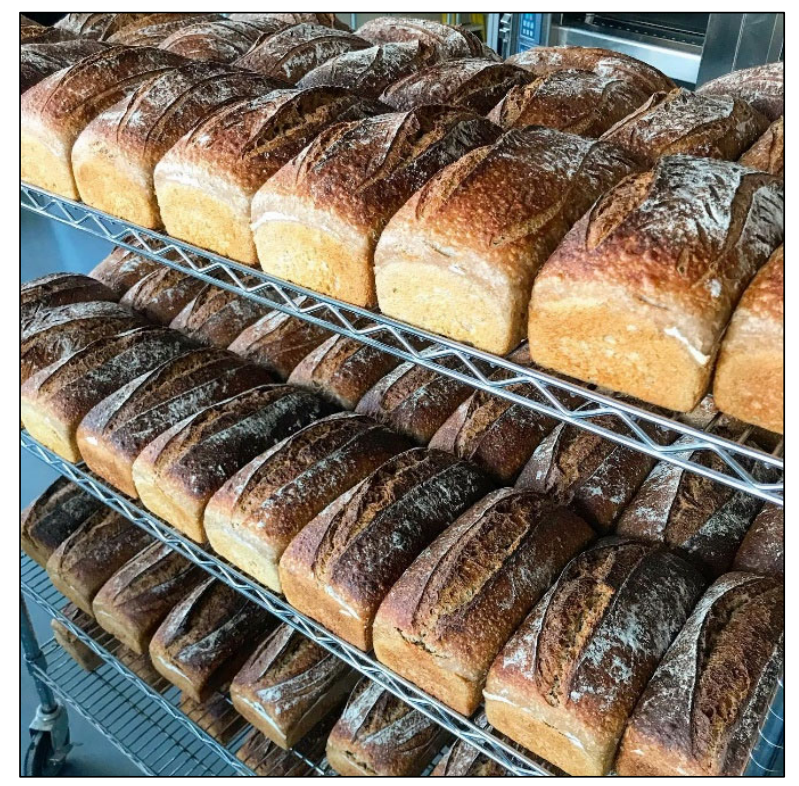

Neighbor Loaves cool on the rack at ORIGIN Breads, a bakery in Madison, Wisconsin, that uses flour and grains exclusively from Meadowlark Organics, an organic farm in Wisconsin's Driftless Region. The loaves are baked with $100 \%$ organic whole-grain, stone-milled wheat flour. 
Many bakeries have had to trim hours and furlough employees to be able to keep operating, but Neighbor Loaves is helping to stabilize production. In Bloomington, Indiana, Muddy Fork Farm \& Bakery joined the program immediately and was able

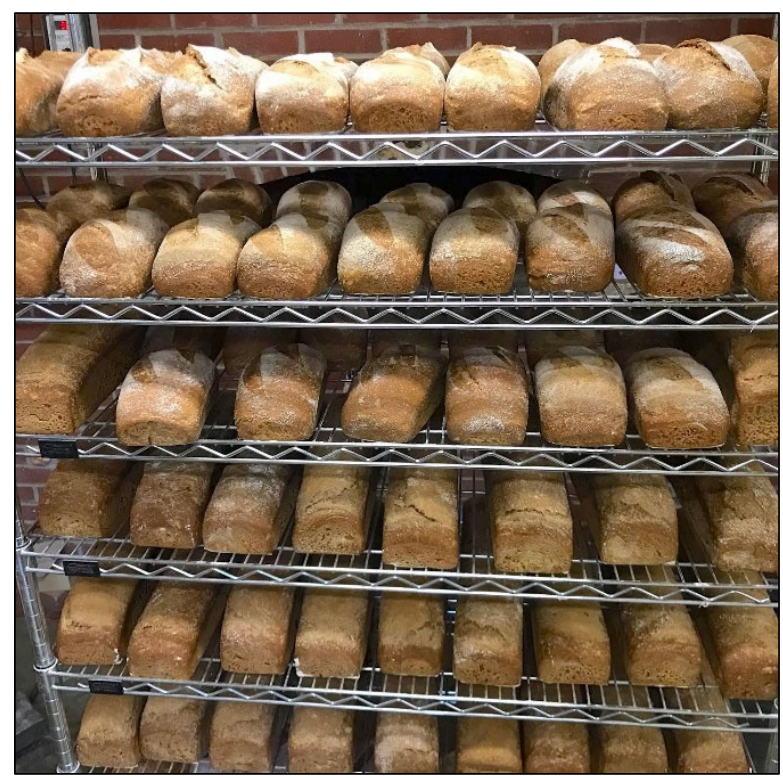

These Neighbor Loaves, baked with Illinois-grown organic grain, will feed Bloomington, Indiana, residents served by Mother Hubbard's Cupboard, and help the bakers at Muddy Fork Farm \& Bakery remain financially stable during the COVID-19 crisis.

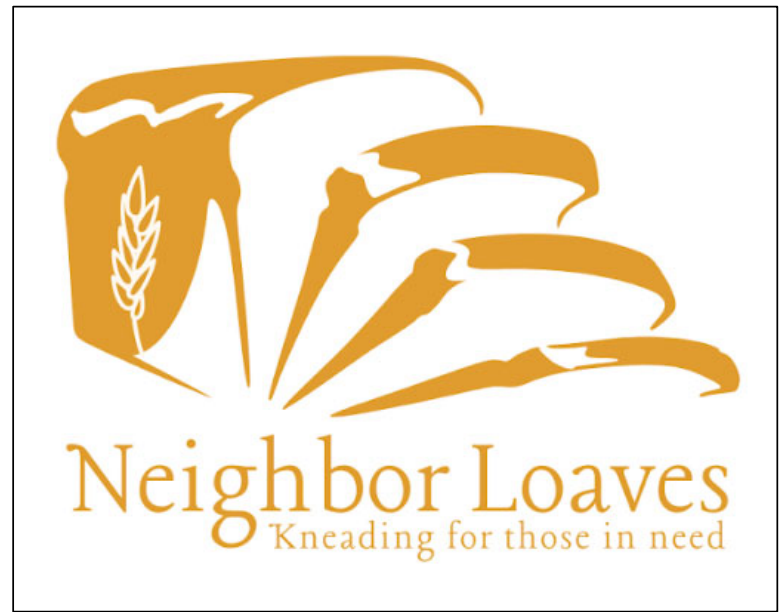

The Neighbor Loaves logo, designed by The Tiny Seed Project for The Northeast Grainshed..

\section{For more information}

Contact Alyssa Hartman through the Artisan Grain Collaborative's Neighbor Loaves page: http://graincollaborative.com/neighbor-loaves/ to boost hours for its three part-time employees. These people had lost their other employment because of Indiana statewide closures. Increasing production through Neighbor Loaves allowed the bakery to increase the hours of the employees and cover their lost income.

Another regional grain group I work with, the Northeast Grainshed, is helping bakeries and mills support food pantries in remaining stocked through Neighbor Loaves. Of course, the habit of generosity is common to bakers, and many were already doing something similar. When I called the milling bakery nearest me in upstate New York, Sparrowbush Bread, to talk about flour, co-owner Antoine Guerlain was driving to upstate Vermont to fetch a bread slicer for his own donation program. Could he use the Neighbor Loaves name, he asked? I reassured him that the name and plan are meant to be copied.

"Fundamentally, we've tried to ask ourselves 'what do we have that can be shared,' amid this scary and challenging time," he wrote on the farm and bakery's website. Sparrowbush is now baking 120 loaves a week for two feeding efforts: a youth center in the city of Hudson that has become a food distribution hub, and a rural group, too. Money is coming in via many routes: individuals are buying bread for neighbors, and two donations (one of US $\$ 500$ from a group and one of US $\$ 2,500$ from an individual) are supporting the program. The hardest part of the work, Antoine told me, is that he has no feedback; he's used to the face-toface connection of farmers market sales, and it's tough to serve a new group of eaters without knowing how they are reacting to the bread.

I love the way this project protects everyone in the grain supply chain and connects to the emergency feeding system. Maybe these relationships can continue in whatever "next normal" emerges. Fresh, local flour deserves to be in everyone's homes and in everyone's bread. 


\section{Infographic for Neighbor Loaves}

https://i0.wp.com/graincollaborative.com/wp-content/uploads/2020/04/Neighbor-Loaves generalgraphic.png

\section{Some Participating Bakeries}

Hewn Bread: https://www.hewnbread.com/

Hillside Food Pantry: http://www.hillsidepantry.org/

Madison Sourdough: https://www.madisonsourdough.com/

Meadowlark Organics: https://www.meadowlarkorganics.com/our-farm-1

Muddy Fork Farm \& Bakery: http://muddyforkbakery.com/

ORIGIN Breads: http://www.originbreads.com/

Sparrowbush Bread: https://sparrowbushfarm.com/covid19 